Original Research Paper

\title{
Protective Effect of Galactomannan Extracted from Iraqi Lycium Barbarum L. Fruits Against Alloxan-Induced Diabetes in Rats
}

\author{
Adnan J.M. Al-Fartosy \\ Department of Chemistry, College of Science, University of Basrah, Iraq
}

\author{
Article history \\ Received: 20-08-2014 \\ Revised: 26-10-2014 \\ Accepted: 02-12-2014 \\ E-mail: dr.adnanfrtosy@yahoo.com
}

\section{Introduction}

Diabetes mellitus, an endocrine disorder is associated with depleted insulin secretions with altered carbohydrate, lipid and protein metabolism. Complications such as renal failure, coronary artery, cerebral-vascular disease, neurological complications, blindness, limb amputation, long term damage, dysfunctions, failure of various organs and eventually premature death are associated with chronic hyperglycemia (Lanjhiyana et al., 2011). There is a reservoir of basic information that suggests the involvement of oxidative stress in the pathogenesis of diabetes mellitus. It is now recognized that sustained

\begin{abstract}
Lycium barbarum L. (Solanaceae) is widely used in Iraqi Ayurvedic medicine for the treatment of diabetes mellitus. The present investigation was done to evaluate the effects of polysaccharide (galactomannan) from Lycium barbarum L. Fruits (GLBF) on serum blood glucose, serum lipid profile and lipid peroxidation and antioxidant defence in liver and kidney of alloxan-induced diabetic rats. GLBF was found to be non-toxic at $1000 \mathrm{mg} \mathrm{kg}^{-1}$, as no deaths or hazardous signs were recorded during treatment or the observation period ( 24 and $72 \mathrm{~h}$ ) in either control or treated groups of mice. In GLBF $\left(500 \mathrm{mg} \mathrm{kg}^{-1}\right)$, the onset study, repeated administration (once a day for 21 days) of the glibenclamide and GLBF caused a significant reduction in the serum glucose level as compared to the diabetic control group. GLBF (500 mg $\mathrm{kg}^{-1}$ ) treatment prevented a decrease in the body weight of the diabetic rats. Moreover, the results revealed that GLBF (500 mg kg${ }^{-1}$ ) treatment for 21 peroxidation, improving kidney and liver functions, enhanced insulin level and increased the levels of enzymatic and non-enzymatic antioxidants. The Lycium barbarum L. Fruits (GLBF) possess good pharmacological activities, which might be helpful in controls the blood glucose level, improves body weight, lipid metabolism and prevents diabetic complications associated with lipid peroxidation and also maintains the antioxidant enzymatic and nonenzymatic in experimental diabetic rats. The extract seems promising for the development of a phytomedicine for diabetes mellitus.
\end{abstract}

Keywords: Lycium Barbarum, Hypoglycemic, Hypolipidemic, Antioxidant, Alloxan, Galactomannan hyperglycemia in diabetic patient, causes protein glycation and generates free radicals through autooxidation and polyol pathways (Ramakrishna and Jailkhani, 2008; Sharma et al., 2003). High levels of free radicals with concurrent decline of antioxidant defense mechanism may lead to damage of cellular organelles and enzymes (Ottaviano et al., 2008). This can culminate in increased lipid peroxidation and development of insulin resistance, which may consequently promote the development of complications of diabetes mellitus (Demozay et al., 2008). The use of oral antidiabetics is limited due to their adverse side effects including hematological, cutaneous and gastrointestinal reactions, hypoglycaemic coma and disturbances of liver and 
kidney functions. In addition, they are not suitable for use during pregnancy (Alarcon-Aguilara et al., 1998). Medicinal plants continue to provide valuable therapeutic agents, in both modern medicine and in traditional system. The doubts about the efficacy and safety of the oral hypoglycemic agents have prompted a search for safer and more effective drugs in the treatment of diabetes (Reaven et al., 1983). In spite of the fact that insulin has become one of the most important therapeutic agents known to medicine, researchers have been making efforts to find insulin substitutes from synthetic or plant sources for the treatment of diabetes. Many herbs have remained as an alternative to conventional therapy especially in poor areas where insulin is not readily available (Sanchez et al., 1994). Since time immemorial, patients with non-insulin requiring diabetes have been treated orally in folk medicine with a variety of plant extracts. In Iraq, a number of plants are mentioned in ancient literature (Ayurveda) for the cure of diabetic conditions. Lycium barbarum L. (Solanaceae) is widely distributed in Iraq. This plant is well known in Arabic and English system as 'Ausaj, Osaj, Sarim' and 'Box Thorn, Matrimony-Vine', respectively (Chakravarty, 1976). Information gathered from some herbalists (in Basra governorate, Iraq) that the plant is useful to reduce blood sugar, blood cholesterol, rheumatism, heart and liver ailments, infant convulsions and also to aid digestion and to preventing and treating cancer, hepatitis, hypo-immunity function. In this study, the effect of oral dietary supplementation of GLBF in the prevention and/or treatment of alloxan induced diabetes in rat model was investigated. The study also investigated the potential role of antioxidant activity of this material in protecting from diabetes. The findings from this study may add to the overall value of the medicinal potential of the plant.

\section{Material and Methods}

\section{Plant Materials and Chemicals/Reagents}

Lycium barbarum L. fruits, used in this study, were collected on April 2013 from Abu-Al-Khaseeb region (Southern of Basrah), which is the well-known production area of Lycium barbarum L. in Basrah/Iraq. The plant was botanically authenticated and voucher specimens 3943 were deposited in the Herbarium of Basrah (Iraq, Basrah, College of Science, University of Basrah). All the chemicals were purchased from SigmaAldrich Co. (St. Louis, MO), Riedal de Haën (Germany), Fluka (Switzerland), Randox (United Kingdom) and solvents were from E. Merck (Darmstadt, Germany). All of the reagents were prepared in deionized distilled water to eliminate the contamination of metal ions.

\section{Experimental Animals}

Albino rat (150-220 g) of both sex were used for the present study. Healthy albino mice of either sex (20-30 g) were used for study sub-acute (short term) toxicity of polysaccharides (galactomannan) extract (GLBF). The animals, with no prior drug treatment, were housed in polypropylene cages (five in cage) under a $12 \mathrm{~h}$ light $/ 12 \mathrm{~h}$ dark cycle in a controlled temperature room $\left(25 \pm 2^{\circ} \mathrm{C}\right)$. All the animals were acclimatized to the laboratory conditions for a week before use. They had free access to food and water. All studies were carried out by using five groups of six animals (3 males and 3 females).

\section{Extraction of Galactomannan}

Extraction of the water-soluble polysaccharides (galactomannan) from fruits of Lycium barbarum L. was done using the procedure of (Kooiman, 1971), with minor modification. Fruits were dried at $60^{\circ} \mathrm{C}$ and ground to fine powder. The ground powder samples were refluxed to remove lipids with chloroform: methanol solvent $(2: 1)(\mathrm{v} / \mathrm{v})$. After filtering, the residues $(100 \mathrm{~g})$ were air-dried, suspended in $500 \mathrm{~mL}$ distilled water for $3 \mathrm{~d}$ at $0^{\circ} \mathrm{C}$ and were homogenized using a blender. The viscous mass was further stirred using a magnetic stirrer overnight at room temperature and centrifuged at $9000 \times \mathrm{g}$ at $0^{\circ} \mathrm{C}$. The clear supernatant liquid was separated from the residue and an equal amount of $95 \%$ ethanol was added to the supernatant liquid with continuous stirring. The resulting white precipitate was allowed to settle and separated by decantation. The precipitate was washed with ethanol and freeze dried. To purify the gum, the dried gum was redissolved in distilled water with continuous stirring until completely dissolved. Fehling's solution was added to the gum solution resulting in the formation of light blue precipitate. The precipitate was separated by decantation, washed and suspended with distilled water and $2 \mathrm{M} \mathrm{HCl}$ solution. The resulting mixture was stirred and an equal amount of $95 \%$ ethanol was added to regenerate the gum. The galactomannan extract was washed again with ethanol and freeze dried. The dried $L$. Barbarum Polysaccharides (LBP) obtained were stored in a refrigerator till further use.

\section{Toxicity Evaluation in Mice}

To study sub-acute (short term) toxicity, four groups of 9 weeks Swiss albino mice of both sexes (8) ranging in weight from 4-45 $\mathrm{g}$ were used and were orally fed with GLBF in increasing dose levels of $100,500,1000 \mathrm{mg} \mathrm{kg}^{-1}$ body weight. The animals were observed after $30 \mathrm{~min}$ and 2 h. The following profiles were observed (Turner, 1965). Behavioural profile: Alertness, restlessness, irritability and fearfulness. Neurological profile: Spontaneous activities, reactivity, touch response, pain response and gait. Autonomic profile: Defecation and urination.

\section{Induction of Diabetes Mellitus}

The animals were fasted for $12 \mathrm{~h}$ with free access to water prior to the induction of diabetes which was carried out by single intraperitoneal injection of alloxan 
monohydrate dissolved in sterile cold normal saline at a dose of $150 \mathrm{mg} \mathrm{kg}^{-1}$ body weight (El-Demerdash et al., 2005). Since alloxan is capable of producing fatal hypoglycemia as a result of massive pancreatic release of insulin, the rats were treated with $20 \%$ glucose solution intraperitoneally after $6 \mathrm{~h}$. They were kept for the next $24 \mathrm{~h}$ on $5 \%$ glucose solution bottles in their cages to prevent hypoglycemia (Dhanapani et al., 2002). Four days after alloxan injection, the blood samples were freshly withdrawn from tail-tips of the experimental rats by the retro orbital plexus technique using capillary glass tubes. Serum was separated in an electric centrifuge at $3000 \times \mathrm{g}$ for $10 \mathrm{~min}$ and glucose levels was measured using the glucose oxidase peroxidase (GOD-GPD) method (Trinder, 1969) using a commercial kit (Span Diagnostics, Stuart India) and only those rats with fasting blood serum glucose greater than $200 \mathrm{mg} \mathrm{dL}^{-1}$ will be included in the study (Dhanapani et al., 2002).

\section{Experimental Design}

Overnight fasted rats were divided into five groups (n $=6$ ) as follows:

Group I: Served as normal healthy control received only normal saline, $5 \mathrm{~mL} \mathrm{~kg}^{-1}$ body weight (p.o)

Group II: Served as diabetic control received only normal saline, $5 \mathrm{~mL} \mathrm{~kg}^{-1}$ body weight (p.o)

Group III: Diabetic rats served as standard received 10 $\mathrm{mg} \mathrm{kg}^{-1}$ body weight of Glibenclamide (p.o)

Group IV: Diabetic rats received $250 \mathrm{mg} \mathrm{kg}^{-1}$ body weight of GLBF (p.o)

Group V: Diabetic rats received $500 \mathrm{mg} \mathrm{kg}^{-1}$ body weight of GLBF (p.o)

Effect of GLBF on Serum Glucose Level in Normal and Diabetic Rats (Acute Study)

The procedure described by (Badole et al., 2006) was adopted for this study. Animals were fasted for $12 \mathrm{~h}$ but were allowed access to water. Initial blood samples were obtained for determination of basal glucose levels from tail-tips using capillary tubes. Blood samples were then taken at 2, 4, 6 and $24 \mathrm{~h}$ after administration of control, standard or different doses of GLBF.

Effect of GLBF on Serum Level in Normal and Diabetic Rats (Chronic Study)

A published method by (Singh et al., 2010) was adopted, with slight modification. This study was involved administration of control, standard or different doses of GLBF for a period of 21 days. Serum glucose levels were estimated on days $0,7,14$ and 21. Mean changes in serum glucose were calculated.

Effect of GLBF on Body Weight (g) in Normal and Diabetic Rats

This test was assessed according to the method described by (Badole et al., 2006), with minor modification. During the study period of 21 days the rats were weighed daily and their body weights were recorded. From this data, mean changes in body weight and SEM were calculated and tabulated.

\section{Biochemical Investigations}

At the end of the experiment, all the rats were sacrificed by decapitation under light ether anesthesia after fasting for $12 \mathrm{~h}$. Blood samples were collected directly from heart and serum was separated by centrifugation for 5 min and was kept at $-20^{\circ} \mathrm{C}$ for the biochemical assay of creatinine, urea, Alkaline Phosphatase (ALP), Total Cholesterol (TC), Triglycerides (TG) and High Density Lipoprotein (HDL) and total proteins levels (Kumar et al., 2010). The LDLcholesterol level was calculated by using the formula: LDLc $=$ Total cholesterol-(HDLc + (Triglyceride/5)), where $($ Triglyceride $/ 5)=$ VLDL-cholesterol $($ Freidewald 1972). Serum alanine transaminase (ALT) and Aspartate Transaminase (AST) were measured by using NADH oxidase reaction (Neely et al., 1985). Serum insulin levels were determined using insulin ELISA kit (Kratzsch et al., 1990). The organs namely liver and kidney were excised, immediately washed with cold saline. The tissues were weighed and $10 \%$ tissue homogenate was prepared with $0.025 \mathrm{~m}$ Tris- $\mathrm{Hcl}$ buffer, $\mathrm{pH}$ 7.5. After centrifugation at $10,000 \times \mathrm{g}$ for $10 \mathrm{~min}$, the resulting supernatant was used for the estimation of enzymatic and non-enzymatic antioxidants such as Superoxide Dismutase (SOD), (Sajeeth et al., 2011) catalase (Lee et al., 1999), Glutathione Peroxidase (GPx) (Garfinkel et al., 1992) and glutathione (GSH) (Saneviratane et al., 2009). Lipid peroxidation was estimated by thiobarbituric acid reaction in both liver and kidney (Ohkawa et al., 1979).

\section{Statistical Analysis}

The data were expressed as mean values \pm SEM and tested with analysis of variance followed by Dunnett's ttest. P-values $<0.05,0.01$ were considered to be statistically significant.

\section{Results}

\section{Toxicity Evaluation in Mice}

No death or hazardous signs were recorded during treatment or the observation period (24 and $72 \mathrm{~h}$ ) in either control or treated groups of mice with GLBF (100, 500 and $1000 \mathrm{mg} \mathrm{kg}^{-1}$ ). Therefore, $500 \mathrm{mg} \mathrm{kg}^{-1}$ was chosen as the maximum dose for further experimentation.

\section{Effect of GLBF on Serum Glucose Level in Normal and Diabetic Rats (Acute Study)}

Table 1 showed that the blood glucose levels were significantly decreased at time 2,4 and $6 \mathrm{~h}$ after 
administrated of a single dose of GLBF (250 and $500 \mathrm{mg}$ $\left.\mathrm{kg}^{-1}\right)$ with glibenclamide $\left(10 \mathrm{mg} \mathrm{kg}^{-1}\right)$. The reduction in serum glucose from basal value (before) at $6 \mathrm{~h}$ after administration of glibenclamide and GLBF (250 and 500 $\mathrm{mg} \mathrm{kg}$ ) were $180.27,122.53$ and $171.33 \mathrm{mg} \mathrm{dL}^{-1}$, respectively. The onset of the antihyperglyceim effect of glibenclamide and GLBF $\left(500 \mathrm{mg} \mathrm{kg}^{-1}\right)$ were at $2 \mathrm{~h}$ and that of the GLBF $\left(250 \mathrm{mg} \mathrm{kg}{ }^{-1}\right)$ was at $4 \mathrm{~h}$; the peak effect was at $6 \mathrm{~h}$ but the effect waned at $24 \mathrm{~h}$. The significant reduction in serum glucose from basal value (before) at $24 \mathrm{~h}$ was $100.74 \mathrm{mg} \mathrm{dL}^{-1}$.

\section{Effect of GLBF on Serum Glucose Level in Normal and Diabetic Rats (Chronic Study)}

The perusal of Table 2 concerning antidiabetic activity in alloxan induced diabetic rats showed that the test extract (GLBF) in both dose levels, reduces the blood glucose significantly $(\mathrm{p}<0.01)$ starting from 7 day to the end of 21 day of the study in a dose dependent manner, while the standard drug, glibenclamide showed similar effect during the course of the experiment. However the blood glucose level at the end of 21 day was 149.42 and $126.46 \mathrm{mg} \mathrm{dL}^{-1}$ of the groups treated with the doses of GLBF 250 and $500 \mathrm{mg} \mathrm{kg}^{-1}$ respectively, while standard drug showed $117.34 \mathrm{mg}$ $\mathrm{dL}^{-1}$ at the same time. On the other hand, same Table 2 reflects that reducing insulin level in diabetic rats was also significantly improved by treatment of GLBF.

\section{Effect of GLBF on Body Weight (g) in Normal and Diabetic Rats}

In the body weight measurement, normal vehicle control animals were found to be gained in their body weight but diabetic rats showed a significant reduction in the body weight, which reversed significantly $(\mathrm{p}<0.05)$ by GLBF treated groups $(250$ and $500 \mathrm{mg}$ $\left.\mathrm{kg}^{-1}\right)$ and glibenclamide $\left(10 \mathrm{mg} \mathrm{kg}{ }^{-1}\right)$ treated group during 21 days treatment, as shown in Table 3.

\section{Effect of GLBF on Lipid Profile in Normal and Diabetic Rats}

In diabetic rats the administration of GLBF exhibited a very highly significant hypolipidemic effect $(p<0.01)$ as shown in Table 4. When compared to control (healthy rats), serum Total Cholesterol (TC), Triglycerides (TG), LDL and VLDL levels were increased and HDL-c decreased clearly in diabetic rats. The standard drugs as well as GLBF (250 and $500 \mathrm{mg} \mathrm{kg}^{-1}$ ) plant extracts used in the experimental study significantly decreased $(p<0.01)$ the levels of serum cholesterol, triglycerides, LDL levels and serum VLDL, whereas HDL cholesterol level was improved in both standard and test drug, after 21 days treatment.

\section{Effect of the GLBF on Serum Biochemical Parameters in Normal and Diabetic Rats}

The effect of GLBF on liver and kidney functions are represented in the Table 5. The levels of liver function marker enzymes ALT, AST and ALP were significantly elevated in alloxan-induced diabetes. The rats treated with GLBF (250 and $500 \mathrm{mg} \mathrm{kg}^{-1}$ ) showed significant $(\mathrm{p}<0.01)$ reduction in the elevated levels of these enzymes in a dose dependent manner. On the other hand, kidney function markers like creatinine and urea were elevated in the alloxaninduced diabetic rats when compared with the normal rats. GLBF reduced both the levels in dose dependent manner. Also, the lowered level of total protein in diabetic rats was significantly $(\mathrm{p}<0.01)$ elevated, after 21 days treatment (Table 5).

Effect of the GLBF on Lipid Peroxidation and Antioxidants Activities in Liver and Kidney of Normal and Diabetic Rats

Table 6 and 7 shows the activities of the antioxidants, enzymatic CAT, SOD, GPx and non-enzymatic GSH and lipid peroxidation in liver and kidney of normal and diabetic rats. The above mentioned antioxidants showed a significant decrease $(\mathrm{p}<0.01)$, but the lipid peroxidation level was significantly increased $(p<0.01)$, in both liver and kidney of diabetic rats when compared with normal rats. The standard drugs as well as GLBF (250 and $500 \mathrm{mg} \mathrm{kg}^{-1}$ ) treated rats proved a significant increase $(\mathrm{p}<0.01)$ in the levels of CAT, SOD, GPx and GSH when compared with diabetic rats, whereas lipid peroxidation showed a significant decrease.

Table 1. Effect of GLBF on serum glucose level in normal and diabetic rats (acute study)

\begin{tabular}{|c|c|c|c|c|c|c|}
\hline \multirow[b]{2}{*}{ Groups } & \multirow[b]{2}{*}{ Dose (mg/kg) } & \multicolumn{5}{|c|}{ Blood glucose levels (mg/dL) } \\
\hline & & $0 \mathrm{~h}$ & $2 \mathrm{~h}$ & $4 \mathrm{~h}$ & $6 \mathrm{~h}$ & $24 \mathrm{~h}$ \\
\hline Group I & Healthy control & $113.71 \pm 3.41$ & $112.28 \pm 2.34$ & $113.29 \pm 4.31$ & $115.42 \pm 4.70$ & $114.14 \pm 3.26$ \\
\hline Group II & Diabetic control & $317.37 \pm 5.32$ & $322.12 \pm 2.23$ & $325.83 \pm 4.51$ & $329.85 \pm 2.43$ & $332.56 \pm 2.18$ \\
\hline Group III & Standard & $314.52 \pm 3.61$ & $247.31 \pm 4.84 *$ & $196.79 \pm 4.16^{* *}$ & $134.25 \pm 3.43 * *$ & $203.32 \pm 3.75 *$ \\
\hline Group IV & 250 & $313.85 \pm 1.14$ & $271.23 \pm 3.51$ & $227.42 \pm 2.05^{*}$ & $191.32 \pm 1.35^{* *}$ & $235.51 \pm 2.45 *$ \\
\hline Group V & 500 & $314.64 \pm 4.15$ & $254.14 \pm 2.36^{*}$ & $203.37 \pm 4.21 * *$ & $143.31 \pm 2.42 * *$ & $214.35 \pm 3.47 *$ \\
\hline
\end{tabular}

$\mathrm{N}=6$, values are mean \pm SEM, ${ }^{*} \mathrm{p}<0.05,{ }^{* *} \mathrm{p}<0.01$, as compared to control group 
Adnan J.M. Al-Fartosy / American Journal of Biochemistry and Biotechnology 2015, 11 (2): 74.83 DOI: 10.3844/ajbbsp.2015.74.83

Table 2. Effect of GLBF on serum level in normal and diabetic rats (chronic study)

\begin{tabular}{|c|c|c|c|c|c|c|}
\hline \multirow[b]{2}{*}{ Groups } & \multirow[b]{2}{*}{ Dose $(\mathrm{mg} / \mathrm{kg})$} & \multicolumn{4}{|c|}{ Blood glucose levels (mg/dL) } & \multirow{2}{*}{$\begin{array}{l}\text { Serum } \\
\text { insulin }(\mathrm{U} / \mathrm{dL})\end{array}$} \\
\hline & & Day 0 & Day 7 & Day 14 & Day 21 & \\
\hline Group I & Healthy control & $114.37 \pm 5.32$ & $114.46 \pm 3.26$ & $113.31 \pm 4.25$ & $112.91 \pm 3.31$ & $4.28 \pm 1.07$ \\
\hline Group II & Diabetic control & $314.24 \pm 2.37$ & $351.47 \pm 2.86$ & $393.31 \pm 4.53$ & $426.12 \pm 3.12$ & $1.19 \pm 0.09$ \\
\hline Group III & Standard & $315.32 \pm 2.47$ & $214.37 \pm 2.91$ & $146.42 \pm 2.51 * *$ & $117.34 \pm 3.12 * *$ & $3.29 \pm 1.76^{* *}$ \\
\hline Group IV & 250 & $319.69 \pm 2.73$ & $250.41 \pm 2.63$ & $196.57 \pm 3.14 *$ & $149.42 \pm 2.34 *$ & $2.18 \pm 1.22 *$ \\
\hline Group V & 500 & $311.73 \pm 3.41$ & $231.27 \pm 1.93$ & $159.46 \pm 4.63 * *$ & $126.46 \pm 4.21 * *$ & $2.79 \pm 1.98 * *$ \\
\hline
\end{tabular}

$\mathrm{N}=6$, values are mean $\pm \mathrm{SEM},{ }^{*} \mathrm{p}<0.05,{ }^{* *} \mathrm{p}<0.01$, as compared to control group

Table 3. Effect of GLBF on body weight $(\mathrm{g})$ in normal and diabetic rats

Body weight (g)

\begin{tabular}{llllll} 
Groups & Dose $(\mathrm{mg} / \mathrm{kg})$ & Day 0 & Day 7 & Day 14 & Day 21 \\
\hline Group I & Healthy control & $206.31 \pm 2.43$ & $212.34 \pm 2.61$ & $215.47 \pm 3.07$ & $219.26 \pm 2.52$ \\
Group II & Diabetic control & $209.24 \pm 1.72$ & $204.17 \pm 1.87$ & $196.23 \pm 1.39$ & $190.19 \pm 1.87$ \\
Group III & Standard & $206.71 \pm 2.64$ & $207.31 \pm 2.03 *$ & $209.34 \pm 1.94^{*}$ & $211.41 \pm 1.61^{* *}$ \\
Group IV & 250 & $208.32 \pm 1.09$ & $206.43 \pm 1.74 *$ & $207.13 \pm 2.07^{*}$ & $208.76 \pm 1.64^{*}$ \\
Group V & 500 & $207.42 \pm 1.46$ & $206.93 \pm 1.14 *$ & $208.17 \pm 1.93^{*}$ & $209.37 \pm 1.73^{*}$ \\
\hline
\end{tabular}

$\mathrm{N}=6$, values are mean \pm SEM, ${ }^{*} \mathrm{p}<0.05,{ }^{* *} \mathrm{p}<0.01$, as compared to control group

Table 4. Effect of the GLBF on lipid profile in normal and diabetic rats

\begin{tabular}{|c|c|c|c|c|c|c|}
\hline \multirow[b]{2}{*}{ Groups } & \multirow[b]{2}{*}{ Dose $(\mathrm{mg} / \mathrm{kg})$} & \multicolumn{5}{|c|}{ Serum lipid profile levels (mg/dL) } \\
\hline & & Total cholesterol & HDL-Cholesterol & Triglycerides & LDL & VLDL \\
\hline Group I & Healthy control & $99.64 \pm 3.51$ & $34.29 \pm 3.12$ & $87.45 \pm 3.23$ & $47.6 \pm 3.44$ & $17.39 \pm 1.47$ \\
\hline Group II & Diabetic control & $177.56 \pm 2.41$ & $23.15 \pm 2.09$ & $172.39 \pm 2.41$ & $119.34 \pm 2.07$ & $34.37 \pm 2.13$ \\
\hline Group III & Standard & $104.51 \pm 3.34 * *$ & $40.34 \pm 3.13 * *$ & $92.17 \pm 2.93 * *$ & $45.41 \pm 3.08 * *$ & $18.23 \pm 2.14 * *$ \\
\hline Group IV & 250 & $128.51 \pm 1.24 *$ & $29.27 \pm 1.71 *$ & $122.24 \pm 1.43 *$ & $74.55 \pm 1.13^{*}$ & $24.34 \pm 1.26^{*}$ \\
\hline Group V & 500 & $112.69 \pm 2.52 * *$ & $34.21 \pm 1.97 * *$ & $102.63 \pm 1.36^{* *}$ & $56.16 \pm 2.45 * *$ & $20.53 \pm 1.66^{* *}$ \\
\hline
\end{tabular}

$\mathrm{N}=6$, values are mean $\pm \mathrm{SEM},{ }^{*} \mathrm{p}<0.05,{ }^{*} \mathrm{p}<0.01$, as compared to control group

Table 5. Effect of the GLBF on serum biochemical parameters in normal and diabetic rats

\begin{tabular}{|c|c|c|c|c|c|c|c|}
\hline \multirow[b]{2}{*}{ Groups } & \multirow[b]{2}{*}{ Dose (mg/kg) } & \multicolumn{6}{|c|}{ Serum biochemical parameters } \\
\hline & & Total protein $(\mathrm{g} / \mathrm{dL})$ & Urea $(\mathrm{g} / \mathrm{dL})$ & Creatinine $(\mathrm{g} / \mathrm{dl})$ & $\mathrm{AST}(\mathrm{U} / \mathrm{L})$ & $\operatorname{ALT}(\mathrm{U} / \mathrm{L})$ & $\operatorname{ALP}(\mathrm{U} / \mathrm{L})$ \\
\hline Group I & Healthy control & $6.43 \pm 1.12$ & $32.47 \pm 2.49$ & $0.83 \pm 0.07$ & $45.31 \pm 1.25$ & $52.94 \pm 2.31$ & $135.21 \pm 1.56$ \\
\hline Group II & Diabetic control & $4.39 \pm 1.67$ & $57.21 \pm 2.82$ & $1.18 \pm 0.06$ & $107.12 \pm 1.34$ & $105.41 \pm 2.11$ & $196.78 \pm 1.83$ \\
\hline Group III & Standard & $6.37 \pm 1.13 * *$ & $35.18 \pm 2.28 * *$ & $0.86 \pm 0.03 * *$ & $48.09 \pm 1.71 * *$ & $52.54 \pm 2.34 * *$ & $136.35 \pm 1.26^{* *}$ \\
\hline Group IV & 250 & $5.28 \pm 0.98 *$ & $44.76 \pm 2.54 *$ & $1.09 \pm 0.07 *$ & $75.11 \pm 1.21 *$ & $64.23 \pm 1.97 *$ & $155.69 \pm 1.73^{*}$ \\
\hline Group V & 500 & $6.23 \pm 1.24 * *$ & $36.53 \pm 1.48 * *$ & $0.91 \pm 0.04 * *$ & $52.07 \pm 1.45 * *$ & $53.03 \pm 2.08 * *$ & $139.94 \pm 1.09 * *$ \\
\hline
\end{tabular}

$\mathrm{N}=6$, values are mean $\pm \mathrm{SEM},{ }^{*} \mathrm{p}<0.05,{ }^{* *} \mathrm{p}<0.01$, as compared to control group

Table 6. Effect of the GLBF on lipid peroxidation and antioxidants activities in liver of normal and diabetic rats

\begin{tabular}{|c|c|c|c|c|c|c|c|}
\hline Groups & Dose (mg/kg) & $\begin{array}{l}\text { LPO (nm } \\
\text { MDA formed/ } \\
\text { mg tissue) }\end{array}$ & $\begin{array}{l}\mathrm{CAT}\left(\mu \mathrm{m} \mathrm{H}_{2} \mathrm{O}_{2}\right. \\
\text { consumed/min } \\
/ \mathrm{mg} \text { protein })\end{array}$ & $\begin{array}{l}\text { SOD (U } \\
\text { /mg protein) }\end{array}$ & $\begin{array}{l}\text { GPx }(\mu \mathrm{g} \text { GSH } \\
\text { utilized/min } \\
/ \text { mg protein })\end{array}$ & $\begin{array}{l}\mathrm{GSH}(\mu \mathrm{g} \mathrm{GSH} \\
\text { consued/min } \\
/ \mathrm{mg} \text { protein) }\end{array}$ & $\begin{array}{l}\mathrm{LPO}(\mathrm{nm} \\
\text { MDA formed } \\
/ \mathrm{mg} \text { tissue) }\end{array}$ \\
\hline Group I & Healthy control & $31.86 \pm 1.28$ & $0.924 \pm 0.04$ & $1.376 \pm 0.02$ & $0.574 \pm 0.04$ & $0.935 \pm 0.05$ & $31.86 \pm 1.28$ \\
\hline Group II & Diabetic control & $64.37 \pm 1.42$ & $0.513 \pm 0.03$ & $0.922 \pm 0.04$ & $0.353 \pm 0.07$ & $0.585 \pm 0.03$ & $64.37 \pm 1.42$ \\
\hline Group III & Standard & $31.06 \pm 1.74 * *$ & $0.914 \pm 0.02 * *$ & $1.311 \pm 0.03^{* *}$ & $0.534 \pm 0.08 * *$ & $0.959 \pm 0.02 * *$ & $31.06 \pm 1.74 * *$ \\
\hline Group IV & 250 & $47.63 \pm 1.88 *$ & $0.747 \pm 0.05^{*}$ & $1.162 \pm 0.04^{*}$ & $0.417 \pm 0.03 *$ & $0.626 \pm 0.05^{*}$ & $47.63 \pm 1.88^{*}$ \\
\hline Group V & 500 & $35.27 \pm 1.96 * *$ & $0.829 \pm 0.03 * *$ & $1.252 \pm 0.05 * *$ & $0.468 \pm 0.04 * *$ & $0.862 \pm 0.07 * *$ & $35.27 \pm 1.96 * *$ \\
\hline
\end{tabular}

$\mathrm{N}=6$, values are mean \pm SEM, ${ }^{*} \mathrm{p}<0.05,{ }^{* *} \mathrm{p}<0.01$, as compared to control group 
Table 7. Effect of the GLBF on lipid peroxidation and antioxidants activities in kidney of normal and diabetic rats

\begin{tabular}{|c|c|c|c|c|c|c|c|}
\hline Groups & Dose (mg/kg) & $\begin{array}{l}\text { LPO (nm } \\
\text { MDA formed/ } \\
\text { mg tissue) }\end{array}$ & $\begin{array}{l}\mathrm{CAT}\left(\mu \mathrm{m} \mathrm{H} \mathrm{H}_{2} \mathrm{O}_{2}\right. \\
\text { consumed } / \mathrm{min} \\
/ \mathrm{mg} \text { protein) }\end{array}$ & $\begin{array}{l}\text { SOD (U } \\
\text { /mg protein) }\end{array}$ & $\begin{array}{l}\text { GPx }(\mu \mathrm{g} \text { GSH } \\
\text { utilized/min } \\
/ \mathrm{mg} \text { protein })\end{array}$ & $\begin{array}{l}\text { GSH }(\mu \mathrm{g} \text { GSH } \\
\text { consued/min } \\
/ \text { mg protein) }\end{array}$ & $\begin{array}{l}\text { LPO (nm } \\
\text { MDA formed } \\
\text { /mg tissue) }\end{array}$ \\
\hline Group I & Healthy control & $26.41 \pm 0.15$ & $0.968 \pm 0.07$ & $0.766 \pm 0.08$ & $0.768 \pm 0.05$ & $0.536 \pm 0.03$ & $26.41 \pm 0.15$ \\
\hline Group II & Diabetic control & $48.35 \pm 0.31$ & $0.643 \pm 0.06$ & $0.442 \pm 0.04$ & $0.450 \pm 0.06$ & $0.346 \pm 0.09$ & $48.35 \pm 0.31$ \\
\hline Group III & Standard & $26.32 \pm 0.27 * *$ & $0.915 \pm 0.04 * *$ & $0.759 \pm 0.03 * *$ & $0.759 \pm 0.09 * *$ & $0.510 \pm 0.06^{* *}$ & $26.32 \pm 0.27 * *$ \\
\hline Group IV & 250 & $34.09 \pm 0.41 *$ & $0.723 \pm 0.03^{*}$ & $0.534 \pm 0.02 *$ & $0.567 \pm 0.04 *$ & $0.423 \pm 0.02 *$ & $34.09 \pm 0.41 *$ \\
\hline Group V & 500 & $29.98 \pm 0.35^{* *}$ & $0.819 \pm 0.02 * *$ & $0.757 \pm 0.03^{* *}$ & $0.669 \pm 0.08^{* *}$ & $0.487 \pm 0.05^{* *}$ & $29.98 \pm 0.35^{* *}$ \\
\hline
\end{tabular}

$\mathrm{N}=6$, values are mean $\pm \mathrm{SEM},{ }^{*} \mathrm{p}<0.05,{ }^{* *} \mathrm{p}<0.01$, as compared to control group

\section{Discussion}

As is the case with other diseases, medicinal plants have been used since ancient times to treat and manage diabetes mellitus in traditional medical systems of many cultures throughout the world (Sathya Meonah et al., 2012). The widespread use of herbal remedies and healthcare preparations, such as those described in ancient texts like the Vedas and Bible have been traced to the occurrence of natural products with medicinal properties (Ajay Kumar et al., 2010). Currently, medicinal plants continue to play an important role in the management of diabetes mellitus, especially in development countries, where many people don't have access to conventional antidiabetic therapies (Blade et al., 2006). The currently available drug regimens for management of diabetes mellitus have certain drawbacks and therefore there is a need to find safer and more effective antidiabetic drugs (Duraipanadiyan et al., 2006). Alloxan causes diabetes through its ability to destroy the insulin-producing beta cells of the pancreas (Sharma and Kumar, 2011). In vitro studies have shown that alloxan is selectively toxic to pancreatic beta cells, leading to the induction of cell necrosis (Jorns et al., 1997). The cytotoxic action of alloxan is mediated by reactive oxygen species, with a simultaneous massive increase in cytosolic calcium concentration, leading to a rapid destruction of beta cells (Szkudelski, 2001). According to earlier studies, plant extracts causes antihyperglycemic effect by promoting regeneration of $\beta$-cells or by protecting these cells from destruction, by restricting glucose load as well as by promoting unrestricted endogenous insulin action. Antihyperglycemic effect may also be caused by the effect of plant extract on $\beta$-cells to release insulin or activate the insulin receptors to absorb the blood sugar and stimulate the peripheral glucose consumption (Jadhav et al., 2009). Present study was undertaken to evaluate the hypoglycemic activity of GLBF in normal and alloxan induced-diabetic rats. The results of both acute and chronic study showed that alloxan-induced diabetic rats presented obvious hyperglycemic symptoms, but GLBF produces a significant antihyperglycemic effect when oral administration to alloxan-diabetic rats (dosage of $500 \mathrm{mg} \mathrm{kg}^{-1}$ is more effective than that of $250 \mathrm{mg} \mathrm{kg}$ ). The comparable effect of the GLBF extract with the reference drug glibenclamide may suggest similar mode of action. Glibenclamide is a potent, second-generation, oral sulfonylurea antidiabetic agent used as an adjunct to diet in order to lower blood glucose levels in patients with diabetes mellitus. The hypoglycaemic action of glibenclamide is due to the stimulation of pancreatic islet cells, which results in an increase in insulin secretion. The effects of sulfonylurea are initiated by binding to and blocking on the ATP-sensitive $\mathrm{K}^{+}$channel, which has been cloned. The drugs thus resemble physiological secretagogues (e.g., glucose, leucine), which also lower the conductance of this channel. Reduced $\mathrm{K}^{+}$ conductance causes membrane depolarization and an influx of $\mathrm{Ca}^{2+}$ through the voltage sensitive $\mathrm{Ca}^{2+}$ channel. Prolonged administration of glibenclamide also produces extra pancreatic effects that contribute to its hypoglycaemic activity (Shah et al., 2006). This let us to consider that GLBF may work by the same mode of action of glibenclamide drug or may act by stimulating utilization of glucose by peripheral tissue or the involvement of hepatic factors like activation of glycogen synthetase or release of somatomedin having insulin like activity or inhibition of glucagon release (Suganya et al., 2012). However, the mechanism of this extract (GLBF) used has not been clearly defined. Further experiments are needed to determine its mechanism of action. Alloxan causes a massive reduction in insulin release by the destruction of $\beta$-cells of the islets of langerhans, thereby inducing hyperglycaemia (Grover et al., 2000). Insulin deficiency leads to various metabolic alterations in the animals viz increased blood glucose, increased cholesterol, increased levels of alkaline phosphate and transaminases (Sharma et al., 2010). The results of the present study indicate that GLBF reduces the glucose level in animals made diabetic with alloxan. Alloxan has been shown to induce free radical production and cause tissue injury. The pancreas is especially susceptible to the action of alloxan induced free radical damage. In the present investigation, repeated administration of GLBF for 21 days has increased the insulin level. Therefore, the antihyperglycemic activity of GLBF was associated with an increase in plasma insulin levels, suggesting that the 
activity could be due to insulinogenic activity of the extract. The increased levels of insulin in diabetic treated rats in this study, indicate that GLBF stimulates insulin secretion from the remnant $\beta$ cells or/and from regenerated $\beta$ cells. Similar effect, i.e., insulinogenic activity with the treatment of some medicinal plants was shown by (Karunanayake et al., 1984; Cakici et al., 1994). Further investigation is expected to characterize the active hypoglycemic principle. Induction of diabetes with alloxan is associated with the characteristic loss of body weight which is due to increased muscle wasting and due to loss of tissue protein. When diabetic rats were treated with GLBF or glibenclamide, the weight losses was recovered and shows an increase in the body weight. The capability of GLBF to protect body weight loss seems to be related to its ability to reduce oxidative damage, its protective effect in controlling muscle wasting i.e., reversal of gluconeogenesis and may also be due to the improvement in insulin secretion and glycemic control (Shirwaikar et al., 2006). Lipid plays an important role in the pathogenesis of complications involved with diabetes mellitus. The elevated levels of serum cholesterol and triglycerides with reduced level of serum HDL cholesterol in diabetic condition, poses to be a rises of factor for developing microvascular complication leading to atherosclerosis and further leads to cardiovascular diseases like coronary heart disease. The abnormal high concentration of serum lipid in diabetic mainly due to increased mobilization of free fatty acids from peripheral fat depots, since insulin inhibits the hormone sensitive lipase, insulin deficiency or insulin resistance may be responsible for dislipidimia (Daisy et al., 2008). Present study showed that alloxan induced diabetic untreated rats showed significantly increased serum lipid profiles except HDL when compared with the control rats. However, treatments with GLBF or glibenclamide were significantly improvement in the lipid profile when compared to the diabetic untreated rats. Similarly the high density lipoprotein which was reduced in the diabetic untreated rats was significantly increased in the groups administered the GLBF extract. The diabetes-induced hyperlipidemia might be due to excess mobilization of fat from the adipose tissue because of underutilization of glucose. The result of our study is in accord with the findings of other researchers who reported that Many plants extracts have potential therapeutic value in combating artherosclerosis which is one of the major complications of diabetes by lowering serum lipids particularly total cholesterol, triglyceride and low density lipoprotein level (Luka and Tijjani, 2013). This effect not only due to better glycemic control but could also been due to inhibition of the pathway of cholesterol synthesis and increased HDL/LDL ratio may be due to the activation of LDL receptors in hepatocyte, which is responsible for taken up LDL into the liver and reduce the serum LDL level (Singh et al., 2010). Liver and kidney damages were the prominent side effect in severe diabetic patients as well as in severe alloxan induced diabetes. The observed marked increases in the activities of aminotransferases (AST and ALT) and Alkaline Phosphatase (ALP) in the diabetic untreated rats are indications that the liver resulted in cytotoxic injury when compared with the control. Larcan et al. (1979) reported that the necrotized property can be occurring in liver of diabetic patients. Therefore, the increment of the activities of AST, ALT and ALP in serum may be mainly due to the leakage of these enzymes from the liver cytosol into the blood stream (Navarro et al., 1993), which gives an indication on the hepatotoxic effect of alloxan. Conversely, a marked decrease in the activities of these marker enzymes was observed in the GLBF extract treated diabetic rats when compared to the diabetic untreated rats which imply a decrease in the rate and magnitude of tissue cell injury and it is also in accord with the observed protective effect of plant extract (GLBF) against alloxan-induced diabetes in rats. Measurement of the activities of "marker" enzymes or biomarkers in body fluids can be used in assessing the degree of assault and the toxicity of a chemical compound on organs/tissues (Mafulul et al., 2013). These results are in agreement with those obtained by Ohaeri (2001). On the other hand, renal disease is one of the most common and severe complications of diabetes. Several tests are commonly used in clinical practice to screen for renal disease, monitor the progression of known disease and monitor the effects of potentially renal toxic drugs. The most common tests include the serum total proteins, urea and creatinine. In the present study, a significant reduction in the level of serum insulin and elevation in the levels of serum creatinine and urea indicate impaired renal function of untreated-diabetic animals when compared with control group. Insulin is a physiological factor, which plays an important role in the maintenance of protein balance, since it not only stimulates the uptake of amino acids and protein synthesis, but also inhibits protein degradation (Pathak and Dhawan, 1988). The extract GLBF was showed significantly increased the total protein and lowered the serum urea and creatinine levels by enhancing the renal function that is generally impaired in diabetic rats. This result is going with a previous study (Daisy et al., 2007).

Like many chronic diseases, diabetes is widely believed to increase oxidative stress. A possible mechanism for oxidative stress in diabetes is autooxidation of sugar and unsaturated lipid that leads to the production of free radicals, which damage the macromolecules (Suganya et al., 2012). Hypoinsulinemia in diabetes increases the activity of the 
enzyme fatty acyl coenzyme A oxidase which initiates $\beta$ oxidation of fatty acids, resulting in lipid peroxidation (Memişoğullari and Bakan, 2004). The involvement of oxidative stress in the causation of diabetes mellitus was well documented and the importance of antioxidants in the duration of diabetes mellitus was also reported. The major organs involved in diabetic complication are liver and kidney. The current study showed a significant elevation of plasma malondialdehyde (an indicator of lipid peroxidation) contents in liver and kidney of diabetic rats. The GLBF significantly reduced the lipid peroxidation product levels in diabetic rats, confirming that GLBF is potent antioxidants. In diabetes an increase in oxidative stress arises due to compromise in natural antioxidant mechanisms and an increase in oxygen free radical production (El-Demerdash et al., 2005). Any compound-natural or synthetic-with antioxidant activity might totally or partly alleviate the oxidative damage (Sepici-Dincel et al., 2007). SOD and CAT are the two major scavenging enzymes that remove radicals in vivo. In the present study, SOD and CAT activities were significantly decreased in the liver and kidney of diabetic rats. A decrease in the activity of these antioxidants can lead to an excess availability of superoxide anion $\left(\mathrm{O}_{2}{ }^{-{ }^{-}}\right)$ and hydrogen peroxide $\left(\mathrm{H}_{2} \mathrm{O}_{2}\right)$, which in turn generate hydroxyl radicals $\left({ }^{\circ} \mathrm{OH}\right)$, resulting in initiation and propagation of lipid peroxides. SOD can catalyze dismutation of $\mathrm{O}_{2}{ }^{--}$into $\mathrm{H}_{2} \mathrm{O}_{2}$, which is then deactivated to $\mathrm{H}_{2} \mathrm{O}$ by CAT or GPx (Pari and Latha, 2004; Kumuhekar and Katyane, 1992). Normally, SOD works in parallel with selenium dependent GPx, which plays an important role in the reduction of $\mathrm{H}_{2} \mathrm{O}_{2}$ in the presence of reduced glutathione forming oxidized glutathione (GSSG) and thus, it protects cell proteins and cell membranes against oxidative stress. GPx has a key role in enzymatic defense systems and reduces organic peroxides into their corresponding alcohols. In our study, GPx activity was significantly decreased in the liver and kidney of diabetic rats. The significant decrease in GPx activity could suggest inactivation by ROS, which are increased in diabetic rats. The decrease may also be due to the decreased availability of its substrate, GSH, which has been shown to be depleted during diabetes (Ugochukwu et al., 2004; Ardestani and Yazdanparast, 2006). GSH is important in the circumvention of cellular oxidative stress, detoxification of electrophiles and maintenance of intracellular thiol redox state. GSH is reported to be essential for recycling of other antioxidants like antioxidant vitamins (Ardestani and Yazdanparast, 2006) and acts as a substrate for GPx and Glutathione-S-Transferace (GST) that are involved in preventing the deleterious effect of oxygen radicals (Sajeeth et al., 2011). In our study, liver and kidney of diabetic rats exhibited a decreased level of GSH which might be due to increased utilization for scavenging free radicals and increased consumption by GPx and GST. Treatment with GLBF and glibenclamide reversed GSH level could be due to decreased utilization of GSH to reduce the lipid peroxidation and also ameliorated SOD, CAT and GPx activities in liver and kidney of diabetic rats. These results suggest that GLBF has free radical scavenging activity, which may exert a beneficial effect against pathological changes caused by ROS. In addition, the over expression of these antioxidant enzymes in diabetic rats treated with GLBF implies that this potential oxidant defense is reactivated by the active principles of GLBF with a resulting increase in the capacity of detoxification through enhanced scavenging of oxy radicals.

\section{Conclusion}

Finally, it is concluded that the consumption of GLBF caused a significant reduction in glucose level of alloxan diabetic rats. The result of the present study showed that GLBF brings back the blood glucose and body weight to normal in diabetic rats. In addition, this agent was capable of improving serum insulin, hyperlipidaemia and the impaired liver and kidney functions. Moreover, the treatment of rats with GLBF for 21 days was effective in controlling the hyperglycemia, hyperlipidaemia and the oxidative damage. This investigation is helpful for understanding mechanism of action of Lycium barbarum L. fruits and its active ingredients and also reveals the potential of Lycium barbarum L. for use as a natural oral agent with hypoglycemic, hypolipidemic and strong antioxidant effects.

\section{Acknowledgement}

Author is highly thankful to the head of Chemistry Department, College of Science, University of Basrah for providing their kind support and facilities to accomplish the present research project within time. Thank is also due to all staff in the Herbarium of Basrah (College of Science, University of Basrah) for authentication of the plant material.

\section{Funding Information}

Funding for this project was received from Department of Chemistry, College of Science, University of Basrah.

\section{Ethics}

Author confirms that this manuscript has not been published elsewhere and is not under consideration by another journal. Also, the manuscript represents honest work and the author has approved the manuscript and agrees with the order in which his name appears on the title page. 


\section{References}

Ajay Kumar, M., M.M. Rao, A. Singh and S. Kumari, 2010. Physicochemical and preliminary phytochemical studies on the rhizome of Acorus Calamus L. Int. J. Pharm. Pharmac. Sci., 2: 130-131.

Alarcon-Aguilara, F.J., R. Roman-Ramos, S. PerezGutierrez, A. Aguilar-Contreras and C.C. Contreras-Weber, 1998. Study of the antihyperglycemic effect of plants used as antidiabetics. J. Ethnopharmacol., 61: 101-110. DOI: 10.1016/S0378-8741(98)00020-8

Ardestani, A. and R. Yazdanparast, 2006. Achillea santolina reduced oxidative stress in the liver of streptozotocin-induced diabetic rats. Pharmacologyonline, 3: 298-308.

Badole, S., N. Patel, S. Bodhankar, B. Jain and S. Bhardwaj, 2006. Antihyperglycemic activity of an aqueous extract of leaves of Cocculus hirsutus (L.) Diels in alloxan-induced diabetic mice. Ind. J. Pharmacol., 38: 49-53.

DOI: $10.4103 / 0253-7613.19853$

Blade, N.M., A. Youla, M.D. Balde, A. Kake and M.M. Diallo et al., 2006. Herbal medicine and treatment of diabetes in Africa: An example from Guinea. Diabetes Metab., 32: 171-175.

DOI: $10.1016 / \mathrm{S} 1262-3636(07) 70265-3$

Cakici, I., H. Conset, T. Baha, I.K. Nurettin and S. Bilge, 1994. Hypoglycaemic effects of Momordica charantia extracts in normoglycaemic or cyproptadine induced hyperglycaemic mice. J. Ethanopharmacol., 44: 117-121.

DOI: 10.1016/0378-8741(94)90077-9

Chakravarty, H.L., 1976. Plant Wealth of Iraq. Ministry of Agriculture and Agrarian Reform, Baghdad, Iraq.

Daisy, P., A.R. Nirmala and M. Rajathi, 2007. Hypoglycemic and other related effects of Elephantopus scaber extracts on alloxan-induced diabetic rats. J. Biol. Sci., 7: 433-437. DOI: $10.3923 /$ jbs.2007.433.437

Daisy, P., J. Eliza and S. Ignacimuthu, 2008. Influence of Costus speciosus (Voen)Sm. Rhizome extracts on biochemicals parameters in streptozotocin induced diabetic rats. J. Health Sci., 54: 675-681. DOI: $10.1248 /$ jhs.54.675

Demozay, D., J.C. Mas, S. Rocchi and E. Van Obberghen, 2008. FALDH reverses the deleterious action of oxidative stress induced by lipid peroxidation product 4-hydroxynonenal on insulin signaling in 3T3-L1 adipocytes. Diabetes, 57: 12161226. DOI: $10.2337 / \mathrm{db} 07-0389$

Dhanapani, S., S.V. Ramasamy, S. Rajagopal and N. Namasivayam, 2002. Hypolipidemic effect of Cuminum cyminum L. on alloxan-induced diabetic rats. Pharmacol. Res., 46: 251-255.

DOI: $10.1016 / \mathrm{S} 1043-6618(02) 00131-7$
Duraipanadiyan, V., M. Ayyanar and S. Ignacimuthu, 2006. Antimicrobial activity of some ethnomedicinal plants used by Paliyar tribe from Tamil Nadu, India. BMC Complementary Alter Medicine, 6: 35-40. DOI: 10.1186/1472-6882-6-35

El-Demerdash, F.M., M.I. Yousef and N.I. El-Naga, 2005. Biochemical study on the hypoglycemic effects of onion and garlic in alloxan-induced diabetic rats. Food Chem. Toxicol., 43: 57-63. DOI: $10.1016 /$ j.fct.2004.08.012

Freidewald, W.T., R.I. Levy and D.S. Frederickson, 1972. Estimation of the concentration of low density lipoprotein cholesterol in plasma without use of the preparative ultracentrifuge. Clin. Chem., $\quad 18$ : 499-502. www.clinchem.org/content/18/6/499.short

Garfinkel, M., S. Lee and E.C. Opara, 1992. Insulinotropic potency of lauric acid: A metabolic rational for Medium Chain Fatty acids (MCF) in TPN formation. J. Surgical Res., 52: 328-333. DOI: 10.1016/0022-4804(92)90111-C

Grover, J.K., V. Vats and S.S. Rathi, 2000. Antihyperglycemic effect of Eugenia jambolana and Tinospora cordifolia in experimental diabetes and their effects on key metabolic enzymes involved in carbohydrate metabolism. J. Ethnopharmacol., 73: 461-470. DOI: $10.1016 / \mathrm{S} 0378-8741(00) 00319-6$

Jadhav, J.K., V.J. Masirkar and V.N. Deshmukh, 2009. Antihyperglycemic effect of Diospyros melanoxylon (Roxb.) bark against Alloxan-induced diabetic rats. Int. J. Pharm. Tech. Res., 1: 196-200.

Jorns, A., R. Munday, M. Tiedge and S. Lenzen, 1997. Comparative toxicity of alloxan, N-alkylalloxans and ninhydrin to isolated pancreatic islets in vitro. J. Endocrinol., 155: 283-293. DOI: 10.1677/joe. 0.1550283

Karunanayake, E.H., J. Welihinda, S.R. Sirimanne and S. Gowri, 1984. Oral hypoglycaemic activity of some medicinal plants of Sri Lanka. J. Ethanopharmacol., 11: 223-231. DOI: $10.1016 / 0378-8741(84) 90040-0$

Kooiman, P., 1971. Structures of galactomannans from seeds of Annona muricata, Arenga saccharifera, Cocos nucifera, Convolvulus tricula and Sophora japonica. Carb. Res., 20: 329-337. DOI: $10.1016 / \mathrm{S} 0008-6215(00) 81387-7$

Kratzsch, J., W. Ackermann, H. Leliacker, W. Berch and E. Keller, 1990. A sensitive sandwich enzyme immunoassay for measurement of insulin on microtitre plates. Exp. Clin. Endocrinol., 95: 229236. DOI: $10.1055 / \mathrm{s}-0029-1210957$

Kumar, S., R. Malhotra and D. Kumar, 2010. Antidiabetic and free radicals scavenging potential of Euphorbia hirta Flower Extract. Ind. J. Pharm. Sci., 72: 533-537. DOI: $10.4103 / 0250-474 X .73921$ 
Kumuhekar, H.M. and S.S. Katyane, 1992. Altered kinetic attributes of $\mathrm{Na}^{+}-\mathrm{K}^{+}$ATPase activity in kidney, brain and erythrocyte membrane in alloxan diabetic rats. Ind. J. Exp. Biol., 30: 26-32.

Lanjhiyana, S., D. Garabadu, P. Bigoniya and A.C. Rana, 2011. Antidiabetic activity of methanolic extract of stem bark of Elaeodendron glaucum Pers. in Alloxanized rat model. Adv. Applied Sci. Res., 2: 47-62.

Larcan, A., H. Lambert, M.C. Laprevote-Heully and N. Delorme, 1979. Light and electron microscopic study of hepatic lesions in the course of hyperlactatemia in diabetic patients. Diabetes Metabolism, 5: 103-112. PMID: 113262

Lee, S., H. Jeong, T. Young, Y.B. Parth and S.H. Kwong et al., 1999. Hypocholesterolemic effect of hesperetin mediated by inhibition of 3-hydroxy-3methylgultaryl coenzyme a reductase and acyl coenzyme a: Cholesterol acyltransferase in rats fed high-cholesterol diet. Nutrit. Res., 19: 1245-1258.

Luka, C.D. and H. Tijjani, 2013. Comparative studies of the aqueous extracts of Ocimum gratissimum, aloe vera, brassica oleraceaand ipomoea batatas on some biochemical parameters in diabetic rats. IOSR J. Pharmacy Biol. Sci., 6: 23-29. DOI: 10.9790/3008-0632329

Mafulul, R., S. Gabriel, C.D. Luka, R.J. Kutshik and U.P. Ojiakobi, 2013. Protective effect of ethanolic extract of gongronema latifolium leaves in alloxaninduced diabetic rats. IOSR J. Pharmacy Biological Sci., 7: 63-68. DOI: 10.9790/3008-0766368

Memişoğullari, R. and E. Bakan, 2004. Levels of ceruloplasmin, transferrin and lipid peroxidation in the serum of patients with Type 2 diabetes mellitus. J. Diab. Complic., 18: 193-197. DOI: $10.1016 / \mathrm{S} 1056-8727(03) 00032-1$

Navarro, C.M., P.M. Montilla, A. Martin, J. Jimenez and P.M. Utrilla, 1993. Free radicals scavenger and antihepatotoxic activity of Rosmarinus. Plant Medicine, 59: 312-314. DOI: 10.1055/s-2006-959688

Neely, W.E., K. O'Classen and M. Gruber, 1985. Determination of serum aspartate aminotransferase with pyridoxal 5'-phosphate in the Technicon SMAC and Du Pont aca compared and correlated with the IFCC recommended method. Clin. Chem., 31: 139-142.

Ohaeri, O.C., 2001. Effect of garlic oil on the levels of various enzymes in the serum and tissue of streptozotocin diabetic rats. Bioscience Reproduct., 21: 19-24. DOI: 10.1023/A:1010425932561

Ohkawa, H., N. Ohishi and K. Yagi, 1979. Assay for lipid peroxidation inanimal tissues by thiobarbituric acid reaction. Anal Biochem., 95: 351-358.

DOI: 10.1016/0003-2697(79)90738-3

Ottaviano, F.G., D.E. Handy and J. Loscalzo, 2008. Redox regulation in the extracellular environment. Circulat. J., 72: 1-16. PMID: 18159092
Pari, L. and M. Latha, 2004. Protective role of Scoparia dulcis plant extract on brain antioxidant status and lipidperoxidation in STZ diabetic male Wistar rats. BMC Comp. Alt. Med., 4: 1-8. DOI: $10.1186 / 1472-6882-4-16$

Pathak, A. and D. Dhawan, 1988. Effects of lithium on the levels of blood urea and creatinine in diabetic rats. J. Med. Sci. Res., 26: 855-859.

Ramakrishna, V. and R. Jailkhani, 2008. Oxidative stress in Non-Insulin-Dependent Diabetes Mellitus (NIDDM) patients. Acta. Diabetol., 45: 41-46. DOI: $10.1007 /$ s00592-007-0018-3

Reaven, E., D. Wright, C.E. Mondon, R. Solomon and H. Ho et al., 1983. Effect of age and diet on insulin secretion and insulin action in the rat. Diabetes, 32: 175-180. DOI: 10.2337/diabetes.32.2.175

Sajeeth, C.I., P.K. Manna and R. Manavalan, 2011. Antioxidant activity of polyherbal formulation on streptozotocin induced diabetes in experimental animals. Der Pharmacia Sinica., 2: 220-226.

Sanchez, F.D., M.J. Game, I. Jimenez and A. Zarzuelo, 1994. Hypoglycemic activity of Juniperus "Berries". Plant Med., 60: 197-200. PMID: 8073081

Saneviratane, K.N., C.D. Hapurachch and S. Ekanayake, 2009. Comparision of the phenolic dependant antioxi-dant properties of coconut oil extracted under cold and hot conditions. Food Chem., 114: 1444-1449. DOI: 10.1016/j.foodchem.2008.11.038

Sathya Meonah, S.T., M. Palaniswamy, S.T.K. Immanuel Moses, L.A. Pradeep Rajkumar and R. Usha Nandhini, 2012. Pharmacognostical and hypoglycemic activity of different parts of Solanum nigrum L. plant. Int. J. Pharm. Pharmac. Sci., 4: 221-224.

Sepici-Dincel, A., S. Açikgöz, C. Cevik, M. Sengelen and E. Yeşilada, 2007. Effects of in vivo antioxidant enzyme activities of myrtle oil in normoglycaemic and alloxan diabetic rabbits. J. Ethnopharmacol., 110: 498-503. DOI: 10.1016/j.jep.2006.10.015

Shah, S.N., S.L. Bodhankar, S.L. Badole, H.V. Kamble and V.J. Mohan, 2006. Effect of trigonelline: An active compound from Trigonella foenumgraecum Linn. in alloxan induced diabetes in mice. J. Cell Tissue Res., 6: 585-590.

Sharma, S.B., A. Nasir, K.M. Prabhu, P.S. Murthy and G. Dev, 2003. Hypoglycaemic and hypolipidemic effect of ethanolic extract of seeds of Eugenia jambolana in alloxan-induced diabetic rabbits. J. Ethnopharmacol., 85: 201-206. DOI: $10.1016 / \mathrm{S} 0378-8741(02) 00366-5$

Sharma, U.S. and A. Kumar, 2011. Anti-diabetic effect of Rubus ellipticus fruit extracts in alloxan induced diabetic rats. J. Diabetology, 2: 1-6.

Sharma, V.K., S. Kumar, H.J. Patel and S. Hugar, 2010. Hypoglycemic activity of Ficus glomerata in alloxan induced diabetic rats. Int. J. Pharmac. Sci. Rev. Res., 1: 18-22. 
Shirwaikar, A., K. Rajendran and B. Rakesh, 2006. Effect of aqueous bark extract of Garuga pinnata Roxb. in streptozotocin nicotinamide induced typr-II diabetes mellitus. J. Ethnopharmacol., 107: 285-290. DOI: $10.1016 /$ j.jep.2006.03.012

Singh, N.S., M. Geetha, P. Amudha and A. Chakraborty, 2010. Evaluation of anti-diabetic activity of methanol extract of Flacourtia Jangomas (lour) in streptozotocin induced diabetic rats. Int. J. Pharma. Bio. Sci., 1: 1-11.

Suganya, S., R. Narmadha, V.K. Gopalakrishnan and K. Devaki, 2012. Hypoglycemic effect of Costus pictus D. Don on alloxan induced type 2 diabetes mellitus in albino rats. Asian Pacific J. Tropical Disease, 2: 117-123. DOI: 10.1016/S2222-1808(12)60028-0
Szkudelski, T., 2001. The mechanism of Alloxan and Streptozotocin action in B cells of the rat pancreas. Physiol. Res., 50: 537-546. PMID: 11829314

Trinder, P., 1969. Determination of glucose in blood using glucose oxidase with an alternative oxygen acceptor. Ann. Clin. Biochem., 6: 24-27. DOI: $10.1177 / 000456326900600108$

Turner, M.A., 1965. Screening Methods in Pharmacology. 1st Edn., Academic Press, New York, pp: 26.

Ugochukwu, N.H., N.D. Bagayoko and M.E. Antwi, 2004. The effects of dietary caloric restriction on antioxidant status and lipid peroxidation in mild and severe streptozotocin-induced diabetic rats. Clin. Chim. Acta., 348: 121-129. PMID: 15369745 